\title{
Characterizing Milk Supply and Marketing Chains and Losses in Wolmera and Ejere Districts of Ethiopia
}

\author{
Tadesse Kenea Amentae*, Girma Gebresenbet, David Ljungberg \\ Division of Logistics, Department of Energy and Technology, Swedish University of Agricultural Sciences, \\ Uppsala, Sweden \\ Email: "tadesse.kenea.amentae@slu.se, girma.gebresenbet@slu.se, david.ljungberg@slu.se
}

Received 25 August 2015; accepted 1 December 2015; published 4 December 2015

Copyright (C) 2015 by authors and Scientific Research Publishing Inc.

This work is licensed under the Creative Commons Attribution International License (CC BY). http://creativecommons.org/licenses/by/4.0/

(c) (7) Open Access

\section{Abstract}

This study was made with the purposes of characterizing milk supply and marketing chains, postproduction losses of milk, and evaluating the potential of supply chain management approach to reduce milk losses in Ethiopia. Primary data were collected by semi-structured survey questionnaire and interview of key informants. The collected data were analyzed using SPSS and Microsoft Excel sheets. Mapping, characterizations, and descriptive statistics were used to analyze the collected data. Both quantitative and qualitative-narrative methods were used in analysis. The finding revealed that farmers, cooperatives/unions, traders, and catering institutions were the major chain actors in milk chain in the study area. With $\mathbf{7 3 \%}$ of milk sold by farmers passing through cooperatives/unions to the next chain actors, cooperatives/unions were the focal firms in this supply chain. Production was characterized by smallholders with few numbers of cows and low productivity of milk per cow per day. Cow breed and lack of access to credit were identified as critical resource and the most constraint that hinder production improvement. Marketing relationships among the chain actors were characterized as lacking long-term market orientation and were mostly on the spot and transaction based. The assessment on the enabling environment indicated further need of support from governmental and non-governmental stakeholders to build the capacity of chain actors, particularly the farmers. The study indicated existence of significant amount of milk losses in the milk chain. With $39 \%$ of the total losses happening at cooperatives/ union stage, cooperatives/unions were identified as loss hotspot point in the chain. Poor milk handling practice at the collection points, lack of immediate acceptors, milk carrying tools used, means of transport used, and ineffective communication with other partner in the chain were identified in order of severity as important problems causing milk losses in the study area. Based on the study results and review of others' work in similar contexts, this study argued for SCM to be part of solution in improving this dairy chain. The study showed cases where effectively imple-

${ }^{*}$ Corresponding author.

How to cite this paper: Amentae, T.K., Gebresenbet, G. and Ljungberg, D. (2015) Characterizing Milk Supply and Marketing Chains and Losses in Wolmera and Ejere Districts of Ethiopia. Journal of Service Science and Management, 8, 823-843.

http://dx.doi.org/10.4236/jssm.2015.86084 
mented SCM approach converted dairy chains from chains characterized by dismantled, high conflicts of interests among the chain actors, and high losses of food in the chain to chains with mutual interest trying to maximize the profit to the whole chain actors. Integrated and collective actions by all chain actors aiming at reducing costs, improving quality, and minimizing food losses in the chain were central to these efforts. Therefore, SCM approach needs to be part of the solution in increasing profitability and reducing milk losses in Ethiopia in general and in the study area in particular. However, the needs for detailed further study, some of which are recommended by this study, are worthwhile.

\title{
Keywords
}

\author{
Supply and Marketing Chains, Dairy/Milk, Post-Production Losses, Supply Chain Management \\ (SCM), Ethiopia
}

\section{Introduction}

\subsection{Background}

Feeding 9 billion people by 2050 that requires food production increase by $70 \%$ was a repetitively mentioned challenge of the world [1]-[3]. On the other hand, the existing global situation in food sector is not cheering. The World Food Program [4] released hunger map on which it stated "about 805 million people or 1 in 9 of the world's population go to bed hungry each night". These results are clear calls for the scientific community to continue with inquires and solutions to food security problems both locally and globally. The food security issue may be discussed under three major elements of equations. The first two which have been more discussed are related to population and food production including productivity. The third element which has been relatively less discussed but gaining better attention nowadays is the issues of food losses across food value chains. Significant amount of food produced with the scarce resources has been lost before reaching consumers. For example, [5] noted that $25 \%$ of the global food produced was lost within the food supply chain before consumption and [1], roughly estimated that global food losses could be $30 \%$ to $40 \%$. Lack of effective supply chain management practices could be one of the major reasons for food losses, hence analyzing and improving food supply chains may reduce food losses. [5] supposed that by making food supply chain efficient, half of the global food losses could be saved and that could feed one billion extra people. Food losses are global problems. However, the stages of food losses and reasons for food losses vary [6], noted that higher food losses happen at early stage of the food supply chain and at consumer level for developing nations the reason being "human action or inaction." According to the author, in developing countries food losses are high in almost the entire chain due to the "poor state of the food supply chains". One of food commodities subject to loss is milk. Milk loss is one of the major problems in East Africa [7], reported total value of milk post-harvest losses of 9.9, 14.2, 17.8, and 23.9 million US dollar per year for Tanzania, Ethiopia, Kenya, and Uganda, respectively. The authors indicated that the milk losses were mainly due to spillage and spoilage caused by inappropriate handling practices, poor market access, and electric power irregularities. This study focuses on characterization of supply and marketing chains and postproduction losses of milk in Ethiopia.

\subsection{Literature}

\subsubsection{The Link between Food Supply Chain Management and Food Losses}

[8], defined supply chain management (SCM) as "the management of upstream and downstream relationships with suppliers and customers in order to deliver superior customer value at less cost to the supply chain as a whole.” According to the author, SCM is a process through which relationships between parties in chains is managed to incorporate individual interest to common interest for the whole chain so that the common interest guide the chain. Food supply chain management requires peculiar supply chain management practices as compared with industrial products supply chains. According to [9], the seasonality of both demand and supply; the issues of quality, traceability, safety and food risk management; short shelf live and sensitive demand caused by 
different factors as a result requiring much responsiveness and speed than stock management; and the fact that for production of food high dependence on natural resources such as water and polluter emissions resulted in huge impact on environmental degradation are major important issues that needs to be within attention in agri-food supply chain management.

Inefficiencies and ineffectiveness in food supply chains are major reasons for food losses, particularly in developing countries [2] [5]. The authors noted that the more the food supply chains are extending, the more the food losses are occurring in the supply chains. This is due to the biological nature of food, subject to various forms of degradation. In order to combat these problems, it requires advanced technology which in turn may require high investment in handling, transportation and market infrastructure, which are not easy tasks particularly for developing countries. However, with collective efforts of stakeholders in the SCM process, the problem could be alleviated. Thus, the role of SCM is critical factor to consider in the effort of reducing food losses. The task of SCM needs to begin with clear understanding of the real situation of the supply and marketing chains, which is possible through characterization of each element across the chain for particular food commodities or group of food commodities. Therefore, this study focuses on milk chain, which is one of the major food commodity both globally and in Ethiopian context.

\subsubsection{Milk Supply and Marketing Chain}

According to [10], about 150 million households around the globe are engaged in milk production and supplying to about 6 billion milk consuming people. The study noted that the link between production and consumption for milk involves various chain actors which vary from one context to the other. The study also indicated that there are numerous challenges that hinder the supposed value additions for minimum cost by dairy chains, particularly in the developing countries. Among the listed challenges include: challenges in establishing milk collection and transport system, which is further aggravated by the dispersed settlement of farmers and remoteness of the farming sites from roads and urban centers; seasonality of the milk supply, poor transport infrastructure and other logistics facilities such as cooling facilities, inadequate and/or lack of technology in milk collection and processing, and poor quality of raw milk.

\subsubsection{Milk Post-Production Loss Assessment Methodology}

Regardless of the necessity of consistent measurement of food losses as a step towards food loss minimization, introducing appropriate methods of estimating food losses across the food value chain remains a challenge. Estimating milk losses across supply and marketing chain is not an exception to this difficulty. From management point of view, it needs a clear measurement to determine the amount of losses i.e., we know it, if we measure it. However, as indicated by [11], the concept of measuring food loss is somehow debatable. That is, if we can measure food loss, it means the loss is somehow known and if it is known, we may not let it lost. Regardless of the controversy and difficulty of measuring food losses, there are two commonly used methods to estimate post-production food losses [11]. The first method is measuring actual loss by following a particular food commodity from production to consumption through measuring weight and/or quality losses at each stage it passes. This approach, though difficult particularly for some commodities, provides better estimate of food losses. An example is grain loss assessment manual developed by [12]. The second method is to use estimates by those who experience the food losses using questionnaire. This method is relatively easy but difficult to trust the estimated figures of food commodity losses. This second method was employed in this study.

\subsection{Problem Statement}

With about 52 million head of Cattles [13], Ethiopia has high potential in milk production and consumption which can alleviate food security problems of the nation. Regardless this potential, the Ethiopian dairy sector remains incapable of meeting local demand that the country is losing high amounts of money for imports of dairy products. In Finfinnee (capital of Ethiopia), 8\% of the dairy products consumption was from import [14]. The country import of milk and milk products was showing dramatic increasing trend and within five years Ethiopia's value of imported milk and milk products increased by 142\% rising from birr 48,951,297 in 2005 to 118,559,962 in 2010 [15]. On the other hand, the problem of food insecurity in Ethiopia remains intact (WFP, 2014). To combat these problems, in addition to the efforts of increasing production and productivity, we believe critical investigation in dairy supply and marketing chains has paramount contribution. This enables to 
identify inefficiencies across the dairy value chains and identify necessary interventions. This leads to the situation where the produced dairy products reach ultimate consumers at the right condition and minimized losses.

\section{Objectives of the Study}

The main objective of the study was to characterize the supply and marketing chains and losses of milk in the study area. The specific objectives were to:

1) map-out and analyze milk supply and marketing chains,

2) assess post-production milk losses and factors causing the losses, and

3) evaluate the potential of supply chain management approach for improving the dairy chain performances including reduction of post-production losses of milk in the study area.

\section{Materials and Method}

\subsection{Study Site, Sampling, and Data Collection}

The study was conducted in two districts of central part of Ethiopia: Ejere and Wolmera (see Annex 2). These districts were purposefully selected because of their potential for dairying and the present increasing trend of dairy production observed in these areas. Their geographical position of nearness to the capital city, 40 - $60 \mathrm{kms}$ to west, also made the two districts areas of operation for a number of the dairy processing plants and commercial oriented dairy farmers are common in these districts.

In the study, different dairy value chain participants were included for the fulfillment of the study objectives. As the study addresses, heterogeneous population groups participating in the milk supply and marketing chains, a mixed sampling technique was used. For dairy farmers, referring to lack of previous study indicating the variance and proportions with regards to the variables assessed, simple random sampling formula by [16] was employed with $p$ value of $80 \%$ and confidence level of $95 \%$. Thus, $n$ value estimated using

$$
n=\frac{z^{2} p \cdot q}{e^{2}}
$$

where: $n$ is sample size; $z$ is value of standard variate from normal curve; $p$ is estimated population proportion; $q$ is $1-p$; and $e$ is error term (5\%). Even though $p$ value of $50 \%$ could give highest sample size, it was limited to $80 \%$ due to resource constraints and consistency observed during the pilot study. Accordingly, the farmer respondent sample size was determined to be 246 but in the process of selecting from stratified areas under the two districts, 262 dairy farmers were randomly selected and included in the study from the two districts.

$$
\frac{1.96^{2} \times 0.8 \times 0.2}{0.05^{2}}=246
$$

Semi-structured questionnaire translated to local language was used to gather the data. Beside farmers, one dairy union, three primary dairy cooperatives, six traders, three processors, and six catering institutions were purposively selected and the institutional representatives (at least three from all) were interviewed and observation of the real situations at their business sites were made. Information collected during the pilot study and consultative workshop combined with relevant literature was used as a base for the development of semi-structured survey questionnaire.

\subsection{Data Analysis}

The primary data collected was organized and analyzed using SPSS and excel sheets; mapping, characterization, and descriptive statistics were employed. The milk value chain was described quantitatively and qualitatively. The description was made for production, marketing, relationships, logistics practices, and some of the enabling environment for the chain actors. Loss assessment was made using a self-estimate approach where the chain actors gave the estimated milk loss percentage from what they produced or purchased before passing to the next chain actor. The average was calculated for each chain actor's category, which was used as a base for estimation of quantity loss of milk relating to production and marketing distribution data. The factors causing milk losses were assessed using Likert-scale rating methods [17], where the respondents evaluated factors from very low loss causing to very high loss causing. 


\subsection{Scope of the Study}

The scope of this study was limited to the general characterization of milk supply and marketing chains in the study areas that includes production, marketing, relationships and logistics practices. The detail analysis of governance structure was not made and could be a direction for future work. Dairy farmers included in this study were those commercial oriented and engaged in dairying as a substantial contribution to their income and livelihood support. Therefore, don't represent the majority of Ethiopian farmers in the rural part of Ethiopia who raise animals for other farming activities and whose dairy products chain is not clearly observable. Moreover, the post-harvest milk loss assessment was made focusing only on the segment of the supply chain which covers production through sales and did not covered losses at the consumer stage.

\section{Results}

\subsection{Mapping and Characterization of the Supply and Marketing Chains of Dairy Products}

The flow of dairy products in the supply and marketing chains (Figure 1), in the study area involves a number of chain actors in complicated networks. The flows start from producers/farmers who have a number of alternative buyers for their products. Farmers may sell their dairy products directly to consumers who usually subscribe ahead of time. Farmers could also sell their dairy products to cooperatives/unions, wholesalers, processors, retailers, and catering institutions. Farmers' milk sells distribution by customer category was dominated by cooperatives/unions buying $73 \%$ of the milk sold by farmers. The remaining $27 \%$ of milk sold by the farmers were distributed to wholesalers, processors, consumers and retailers as $18 \%, 6 \%, 2 \%$, and $1 \%$, respectively. Each of the other chain actors in this milk chain has important customers based on their selling distribution. Accordingly, for coops/unions, wholesalers were important customers; for the wholesalers, processors were important customers; for the processors, retailers were major customers and for the retailers, consumers were the sole customers. Note that these percentages were from what is sold out from each stage not from what comes in to the stage as there were shrinkages due to losses at each stage. The flow of dairy between processors and wholesalers as can be seen from Figure 1, is bidirectional where processors buy fresh milk from wholesalers and wholesalers buy processed milk from processors. FM and PM in the flow chart from wholesalers refer to fresh milk and processed milk, respectively.

\subsection{Production}

The results in Table 1 indicated the number of milking cows and their breed owned by respondent farmers. Accordingly, in the study area, $95.8 \%$ of the respondents had at least one hybrid cow, whereas $41.2 \%$ respondents had at least one local cow in their milk cows. For majority of the respondents (50.8\%), milk cows size was 4 to 5 cows followed by 6 to 8 (30.5\%), which implies that vast majority's (81\%) milking cow size was between 4 and 8. The estimated average number of cows per house hold was calculated using the result in Table 1 to be 6 cows per household (see Annex 1b).

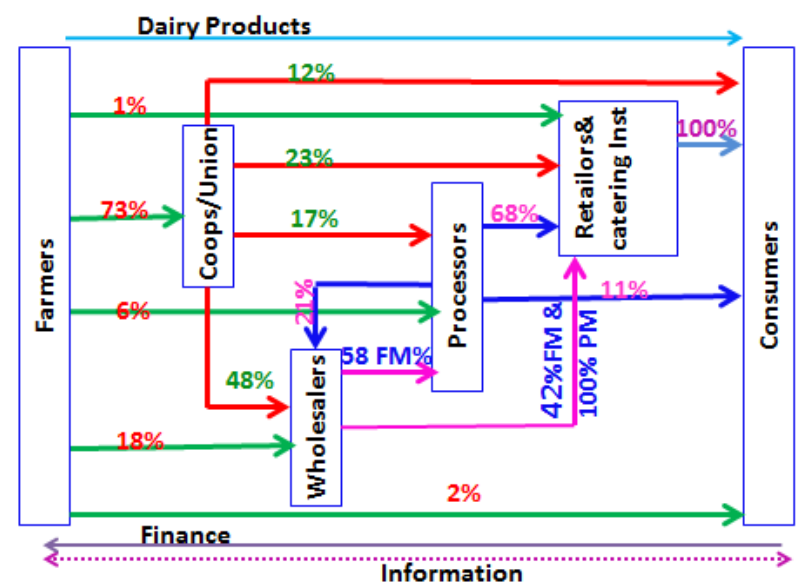

Figure 1. Dairy products flow in supply and marketing chains with selling distribution percentages from each stage. 
Figure 2 reports the average milk production per day per local and hybrid cows in the study area. As per the result, the maximum milk production per day per local cow matches with the minimum milk production per day for hybrid cow which was 5 to 7 litters. On the other hand, majority (53\%) responded that local cow's milk production per day per cow was 1 to 2 liters. For hybrid cows, $40 \%$ responded that milk production per day per cow of 8 to 10 liters while 34\% responded that their hybrid cow's milk production per day was 11 to 15 liters. Local cows refer to cows indigenous to Ethiopia while the hybrid cows refer to cross breeds between foreign milk cows such as Holstein Friesian and indegineous cows. Reference [18] noted that Barca and Boran as popular cattle breeds in Ethiopia among about eight existing breeds in the country. For performance differences among the local and crossbreeds in Ethiopia one may refer to [18].

Figure 2 also reports that it was only very small overlap that was observed at 5 to 7 liters level of production as only $5 \%$ of respondents responded as their maximum production level per day for local breeds and $15 \%$ respondents reported the same level as the minimum production for hybrid cows. A simple estimation calculation (see Annex 1a) from the above data gives an average of 10.54 and 2.56 liter milk productions per day per hybrid cows and local cows, respectively. The result in Figure 3 was that the respondents' supposition on the means for improving production of milk per day per cow to achieve better production. Majority (71\%) of the respondent indicated that improving cow breed was an essential means to improve production as their first choice solution. Improving farming practice and improving cow feed were also indicated as another means of improving productivity but only by limited number of respondents as the first choice. The respondents were asked why they couldn't improve production in the past, and the majority of farmers (Figure 4) indicated that finance or lack of money to invest was their prime problem. Next to finance, access to market was mentioned as the main problem.

\subsection{Marketing Channels}

Based on the data collected at farmer, trader, cooperatives, and union levels, most form of dairy product for sale was fresh milk. Figure 1 presented the milk marketing distribution by buyer categories from farmers through all actors to consumers where each of the chain actors has its principal buyer.

Information from the processors showed that they produce value added dairy products from the raw milk such as pasteurized milk, butter, varieties of cream, varieties of cheese, and yoghurt. The value additions vary among processors where majority of the processors in the area were engaged only in production of pasteurized milk. In

Table 1. Number of milking cows and their breed for respondent farmers.

\begin{tabular}{|c|c|c|c|c|c|}
\hline \multicolumn{3}{|c|}{ Number of milk cows } & \multicolumn{3}{|c|}{ Breed of cows } \\
\hline & Frequency & Percent & & Frequency & Percent \\
\hline $1-3$ & 18 & 6.9 & All Local & 11 & 4.20 \\
\hline 4 to 5 & 133 & 50.8 & All Hybrid & 157 & 59.90 \\
\hline 6 to 8 & 80 & 30.5 & Mixed & 94 & 35.9 \\
\hline 9 to 10 & 19 & 7.3 & Total & 262 & $100 \%$ \\
\hline 11 to 15 & 7 & 2.7 & & & \\
\hline 15 to 25 & 5 & 1.9 & & & \\
\hline Total & 262 & $100 \%$ & & & \\
\hline
\end{tabular}

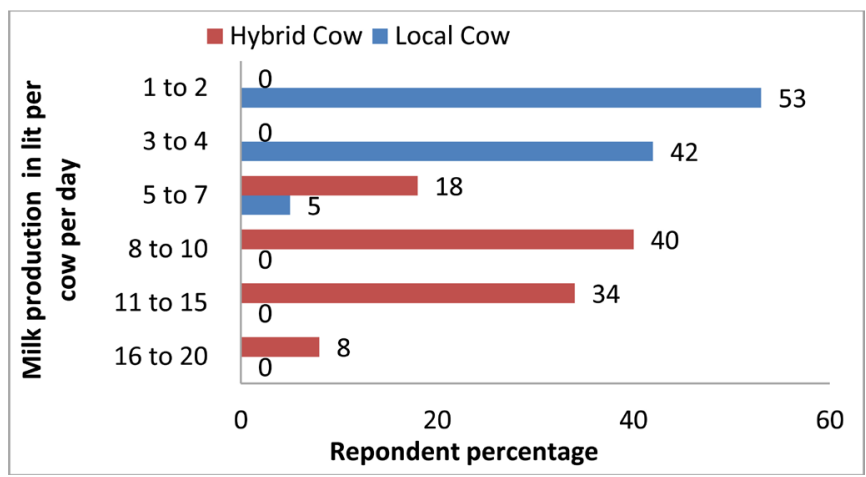

Figure 2. Average milk production per cow per day: local versus hybrid cows. 
catering institution, minor value additions such as boiling and traditional yoghurt (Etitu) making were common practices before selling of milk to consumers as a cup of boiled milk, yoghurt, and/or "makiyato" (milk mixed with coffee somehow similar with Cappuccino). According to the result in Table 2, most farmer respondents

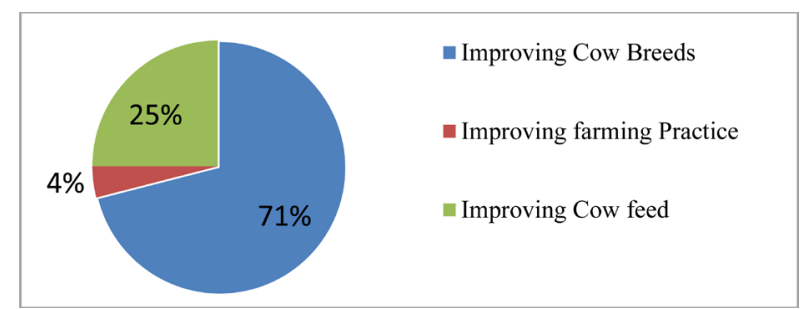

Figure 3. Farmers' first choice solution to improve milk production per cow per day.

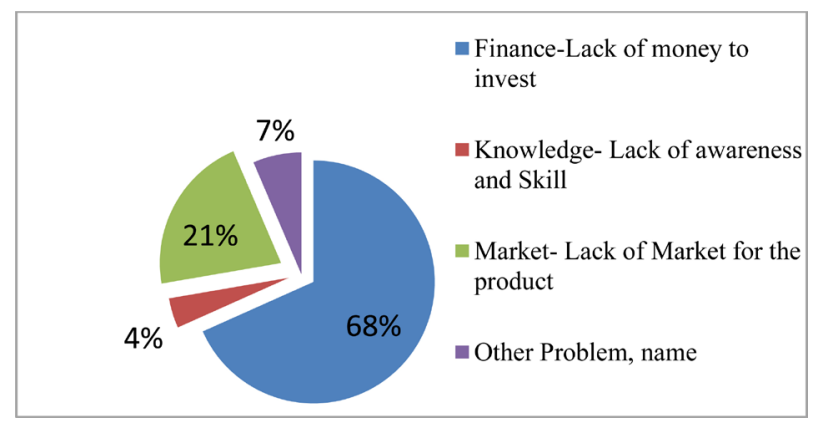

Figure 4. Farmers’ response on the main constraints that hindered them to increase production.

Table 2. Demand, price trends, and nature of competition on sale of dairy products and buying of animal feeds.

\begin{tabular}{|c|c|c|c|c|c|}
\hline \multicolumn{3}{|c|}{$\begin{array}{l}\text { Farmers' evaluation of overall dairy products demand trend } \\
\text { during last } 3 \text { to } 5 \text { years }\end{array}$} & \multicolumn{3}{|c|}{$\begin{array}{l}\text { Farmers' evaluation of dairy products price trend during last } \\
3 \text { to } 5 \text { years }\end{array}$} \\
\hline Trend & Frequency & Percent & Trend & Frequency & Percent \\
\hline Has been getting increasing & 212 & 80.9 & Has been getting increasing & 211 & 80.5 \\
\hline Has been the same & 11 & 4.2 & Has been the same & - & - \\
\hline Fluctuating-sometimes up and sometimes down & 39 & 14.9 & Fluctuating-sometimes up and sometimes down & 51 & 19.5 \\
\hline Total & 262 & 100.0 & Total & 262 & 100.0 \\
\hline \multicolumn{3}{|c|}{$\begin{array}{l}\text { Farmers' evaluation of competition from other dairy farmers to } \\
\text { sell their dairy products }\end{array}$} & \multicolumn{3}{|c|}{$\begin{array}{l}\text { Farmers' evaluation of competition for cow feed with other } \\
\text { dairy farmer }\end{array}$} \\
\hline Nature of competition & Frequency & Percent & Nature of competition & Frequency & Percent \\
\hline Very tough competition & 13 & 5.0 & Very tough competition & 71 & 27.1 \\
\hline Tough competition & 86 & 32.8 & Tough competition & 157 & 59.9 \\
\hline Weak competition & 75 & 28.6 & Weak competition & 23 & 8.8 \\
\hline No competition at all & 88 & 33.6 & No competition at all & 11 & 4.2 \\
\hline Total & 262 & 100.0 & Total & 262 & 100.0 \\
\hline \multicolumn{3}{|c|}{$\begin{array}{l}\text { Farmers' evaluation the price trend of animal feed during past } \\
3 \text { - } 5 \text { years }\end{array}$} & \multicolumn{3}{|l|}{ Farmers' source of cow feed } \\
\hline Trend & Frequency & Percent & Source & Freq & Per \\
\hline Has been getting increasing & 211 & 80.5 & $\begin{array}{l}\text { Own grazing land plus at home fodder } \\
\text { production }\end{array}$ & 15 & 5.7 \\
\hline Decreasing & - & & $\begin{array}{l}\text { Own grazing land plus purchase of additional } \\
\text { fodder from external supplier }\end{array}$ & 153 & 58.4 \\
\hline No change & - & & $\begin{array}{l}\text { At home fodder production plus purchase of } \\
\text { grazing land from external supplier }\end{array}$ & 11 & 4,2 \\
\hline Flactuating & 51 & 19.5 & All purchase from external supplier & 83 & 31.7 \\
\hline Total & 262 & 100.0 & Total & 262 & 100.0 \\
\hline
\end{tabular}


indicated that the demand for dairy products and its price was getting increasing last three to five years. This is an indication for potential development of dairy value chain. However, tough competition on inputs, increasing price of animal feed, and majority of the farmers' dependence on external supplies as source for supplementary animal feed were identified at farmer level as problems. The farmers indicated that they were not benefited from the dairy products price increment as the increment in operational costs, particularly the feed price affected them. Farmers also indicated market problems during fasting seasons when traders don't frequently come to their site to buy milk.

\subsection{Relationships in the Chain}

As the results presented in Figure 1 and Figure 5, indicated most (73\%) of the farmers in the study area sell their dairy products to their cooperatives or union and $79 \%$ of the respondent farmers stated that they were selling to the same buyer each time.

On the other hand, results presented on Figure 6, showed, with regards to the reason for selling to the same buyer where $39 \%$ stated because of ultimate share in the profit of the cooperatives, $20 \%$ stated trust based relationships, while 39\% stated it was because they don't access other buyer. Only few (2\%) of farmer respondents stated that they had written contract with the buyer.

With regards to their primary buyer selection criteria (Figure 7), majority (46\%) stated the ownership interest they had in cooperatives is their primary criteria. For $27 \%, 20 \%$, and $7 \%$ of farmer respondents' price, delivery convenience, and business relationships respectively were their primary criteria in buyer selection decision.

Looking at farmers' relationships with their feed supplies (Figure 8 and Figure 9), majority (62\%) of farmer responded that they had neither formal nor informal relations with the feed suppliers. 33\% of the respondent said that they had only informal trust based relations while only $5 \%$ of the respondents said that they had written contract based agreements with the feed suppliers.

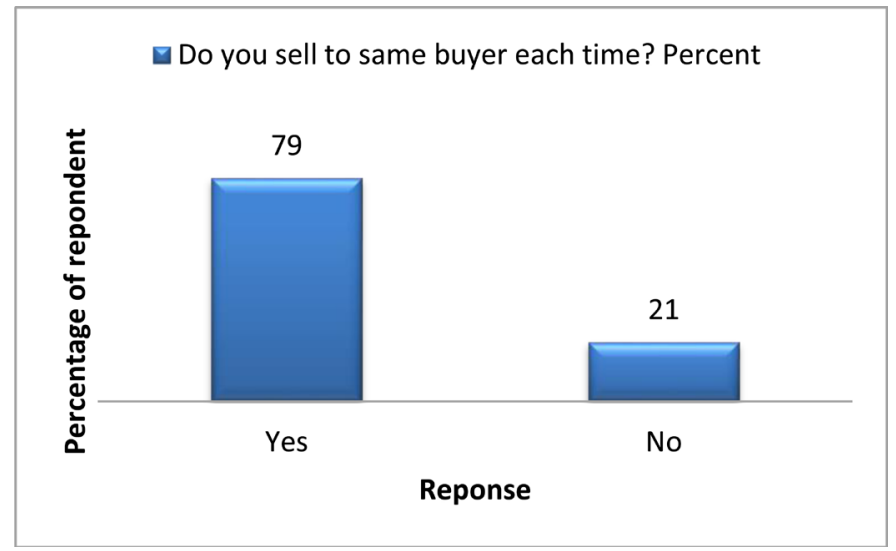

Figure 5. Farmers' response to whether they sell to the same buyer or not.

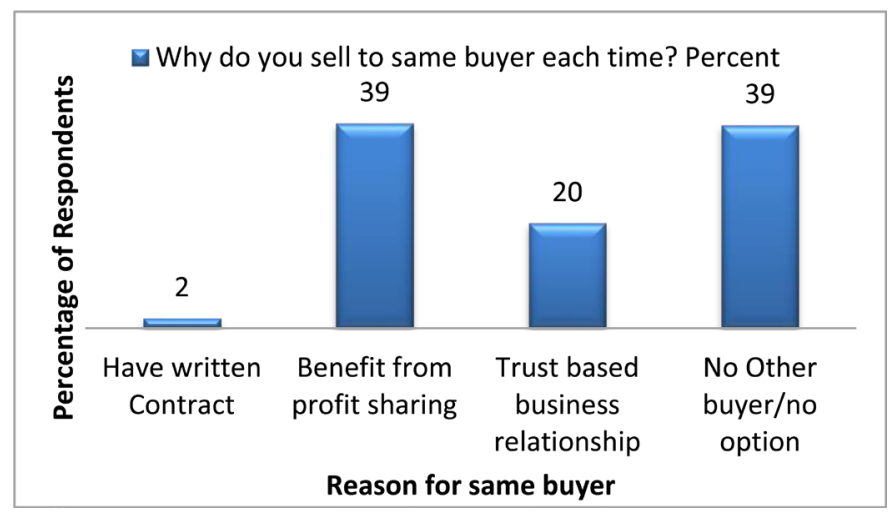

Figure 6. Farmers' reason for selling to the same buyers. 


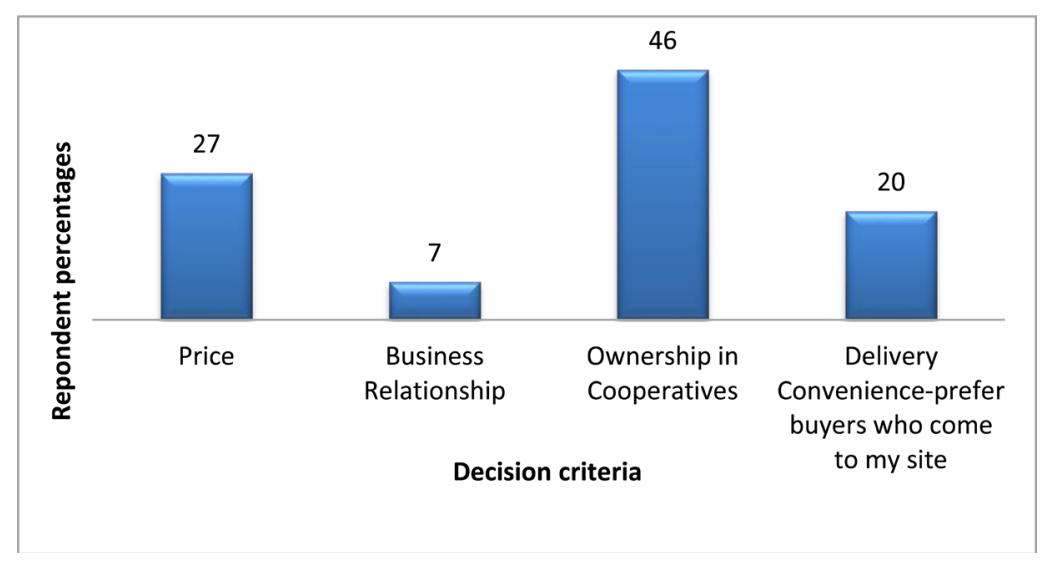

Figure 7. Farmers’ first choice decision criteria in buyer selection.

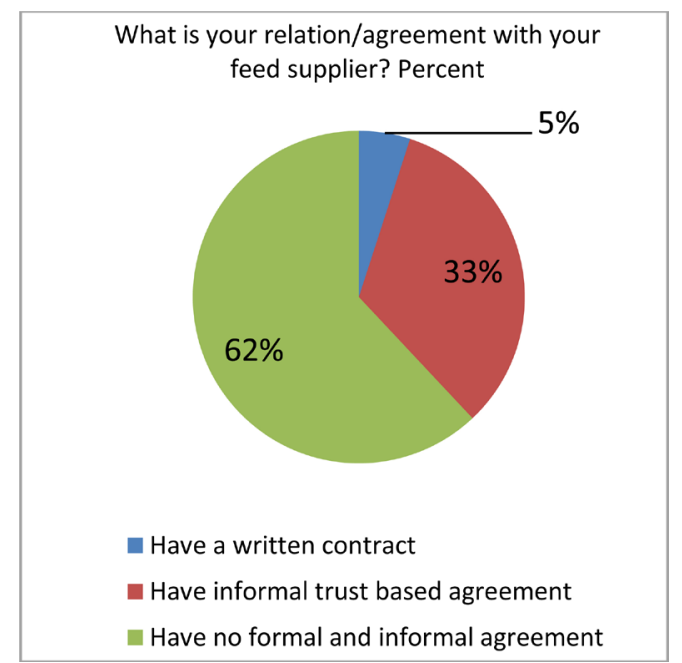

\section{Figure 8. Farmers’ relationship with feed supplier.}

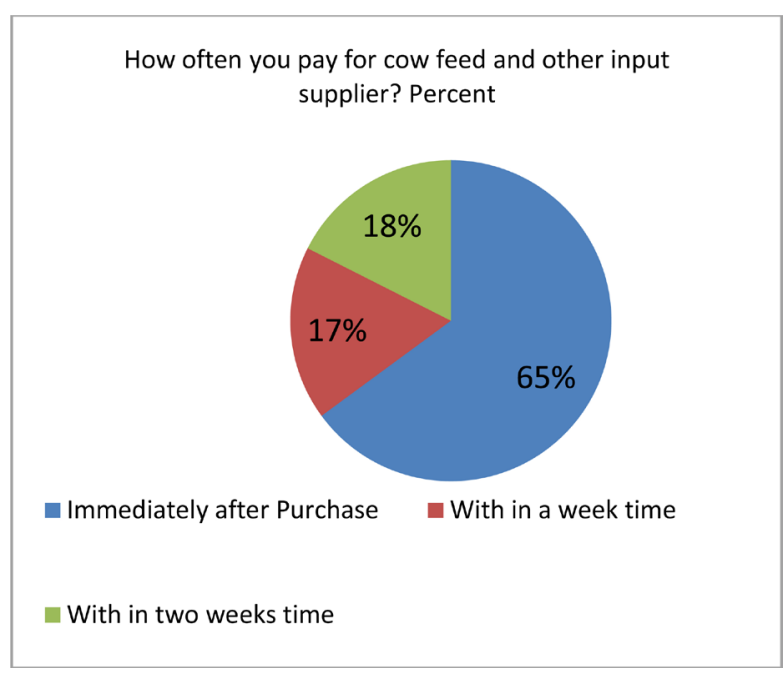

Figure 9. Farmers’ payment time for feed purchase.

The result of dairy farmers' relation with other dairy farmers in the vicinity was presented in Figure $\mathbf{1 0}$ and Figure 11. According to the results, large proportion of respondent farmers (79\%) collaborated with other farmers 


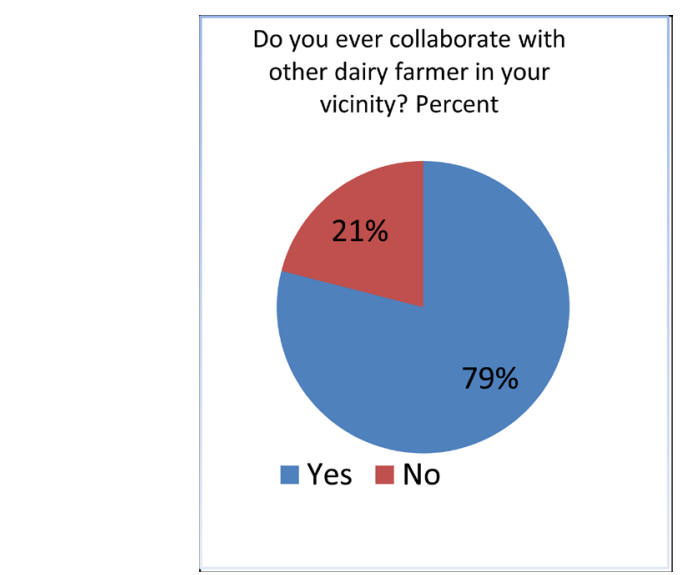

Figure 10. Farmers' relationship with other farmer supplier.

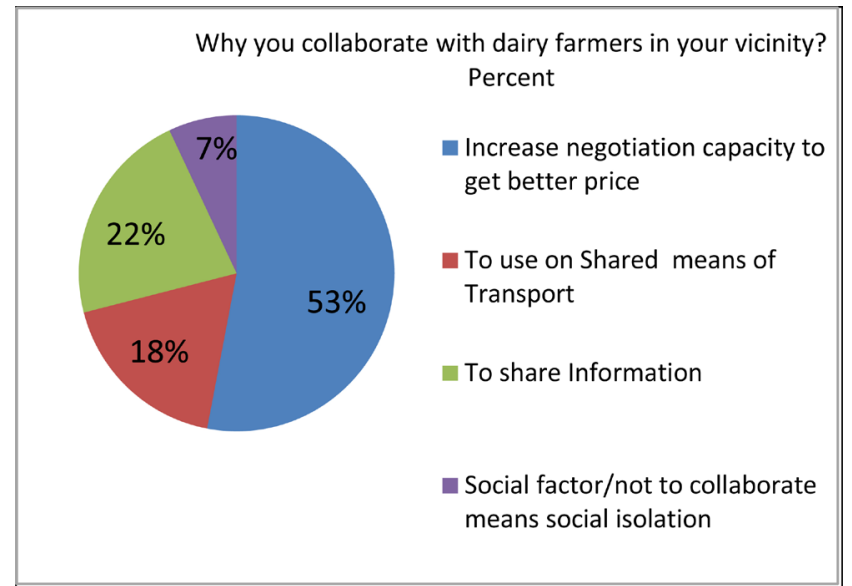

Figure 11. Reason for collaboration with other farmer.

in the area, increasing negotiation capacity to get better price being the major reason of their collaboration.

\subsection{Logistics Practices}

According to the observation made and collected data from the chain actors in the study areas, the logistics practice was described as poor performing, particularly at farmers' level. At peri-urban based farmer level, milk was mostly (89\%) transported by human labor that resulted in delay of reaching collection points, physical losses due to fall-down of people who transport it (usually under age children), and quality losses due to exposure to sun heat and microbial developments. The farmers have no home storage facilities with cooling system. $95 \%$ of the farmer respondent responded that they had no cooling machine for home storage. As a result, they store night milk in water by container but during hot season they claim the existence of loss increases. Traders also claim farmers for mixing night milk with morning milk as a reason for losses and rejection downstream chain. At Urban areas, the logistics practice is relatively better; cars and animal cart were used for transportation. Chain actors here were union, processors, traders, etc, had relatively better established cooling/storage facilities at their sites, but the milk transportation vehicles used were freight transportation vehicles without any cooling system and adjustments for standard milk transportation.

\subsection{Post-Production Losses of Milk}

For this study, post-production milk loss refers to quantity, quality and economic losses. It includes physical loss of milk due to spillage and rejections of milk for quality reasons. Losses which were reported by chain actors may not be total losses as well. For instance, if the fresh milk was rejected at collection point due to quality 
matters, it may not be total loss because the farmer can make butter and cheese out of it. However, the economic values may not be the same with selling fresh milk to the farmers. Therefore, farmers consider milk rejections as losses even though it does not mean total loss. Sometimes rejection also creates forced consumption at home by people or animals which still has some economic value. With the difficulty of addressing these detail issues separately, we only base the assessment based on what the chain actors reported as losses, hence we like to note the limitation in this regard.

According to this study, all respondents who were asked about the existence of milk loss across the chain responded that there was significant amount of milk losses. The average percentage estimated milk losses at each stage of the chain actors were presented in Figure 12. Accordingly, milk loss was highest at cooperatives/union level next to that the farmer level milk loss was significant. By relating the results in Figure 1 and Figure 12 with additional assumptions milk losses at each stage was attempted to be quantified (see Annex 1c). Accordingly, with 219 liters of milk losses per day or 39\% the total losses happening at cooperatives/union stage, cooperatives/unions were identified as loss hotspot point in the chain. Next to that, 207 liters of milk losses per day or $36 \%$ of the total losses happen at farmer stage. Wholesalers, retailers \& catering institutions, and processors quantity and percentage losses in the total loss were identified as 67 liters of milk or $12 \%$ of the total losses, 39 liters of milk or $7 \%$ of total losses and 32 liters of milk or $6 \%$ of the total losses, respectively. In cumulative, 564 liters of milk or $9 \%$ of the total produced (6196 liters of milk) was lost per day in the milk chain for the sampled number of farmers in the study area.

Results presented in Figure 12 indicated that the major factors the chain actors' believe were reasons for the loss of milk in the area. Accordingly, milk handling practice at collection points, lack of immediate acceptor and long waiting time at collection points, milk carrying tools used, means of transport used, and lack or ineffective communication with other partner in the chain were identified in order of severity as important problems causing milk losses.

\subsection{Potential of SCM to Improve the Case Studied Dairy Chain}

Factors behind losses as indicated on Figure 13 and other results presented under the previous sections were summarized in Table 3 to identify the potential of SCM as means for improving this dairy chain. Particularly Figure 13, showed that milk loss causing factors which were manageable through logistics functions improvements and effective SCM system.

\subsection{Some Elements of Enabling Environment}

Integral to the development of effective value chain is the enabling environment in which the supply and marketing chains interact. For this study, chain actors were asked on how they evaluate the support from government and non-governmental organizations, political-legal environment, and physical infrastructure for the

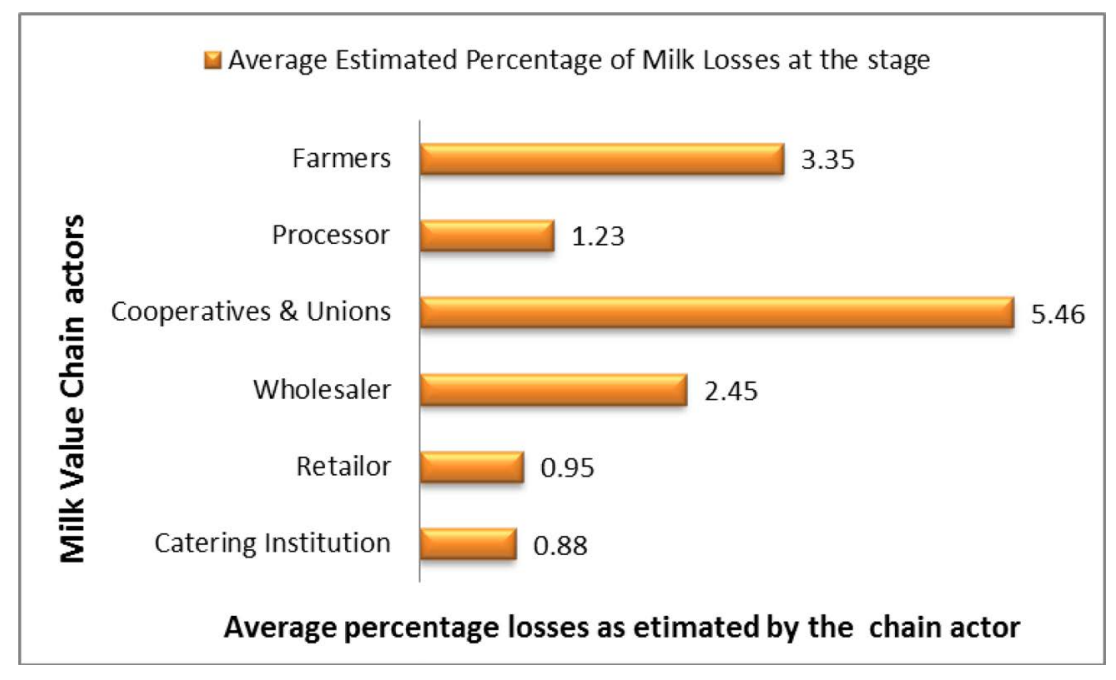

Figure 12. Percentage of milk losses across supply and marketing chains. 
Table 3. Summary of major problems in the studied dairy chain that could be solved by SCM system.

\begin{tabular}{|c|c|c|c|}
\hline Result & Item & Major problems identified & How SCM could solve the problem \\
\hline \multirow{3}{*}{ Figure 13} & \multirow{3}{*}{$\begin{array}{l}\text { Post-production- } \\
\text { loss factors }\end{array}$} & $\begin{array}{l}\text { Poor milk handling practices at collection } \\
\text { points: lack of appropriate facility and } \\
\text { mismanagement. } \\
\text { Lack of immediate milk acceptors/waiting } \\
\text { time at collection points. }\end{array}$ & $\begin{array}{l}\text { SCM could solve the facility related logistics problems } \\
\text { through enhancing collective investments in logistics } \\
\text { tools and infrastructure and enabling coordinated and } \\
\text { integrated use of existing facilities. }\end{array}$ \\
\hline & & $\begin{array}{l}\text { Lack of cooling systems both at home, at } \\
\text { collection points, and during transport. } \\
\text { Poor means of transportation. } \\
\text { Inappropriate milk carrying equipment- }\end{array}$ & $\begin{array}{l}\text { SCM could also alleviate the milk handling practices at } \\
\text { collection centers through awareness creations. With } \\
\text { effective SCM system, qualified and responsible } \\
\text { operators across the whole chain could be achieved. }\end{array}$ \\
\hline & & $\begin{array}{l}\text { plastic, narrow opening difficult to clean } \\
\text { inside. } \\
\text { Poor storage facilities. } \\
\text { Poor communication with other partners in } \\
\text { the chain. }\end{array}$ & $\begin{array}{l}\text { SCM could also improve the communication among } \\
\text { chain actors through effective relationships among chain } \\
\text { actors. Effective and efficient sharing of information is } \\
\text { integral to SCM system. }\end{array}$ \\
\hline Figures 2-4 & Production & $\begin{array}{l}\text { Low milk production per cow per day. } \\
\text { Lack of access to improved cow breeds. } \\
\text { Lack of access to financial services. }\end{array}$ & $\begin{array}{l}\text { The farmers could get support from downstream chain } \\
\text { actors in terms of better access to the improved cow } \\
\text { breed and financial services. }\end{array}$ \\
\hline \multirow{2}{*}{ Figures 5-9 } & \multirow{2}{*}{$\begin{array}{l}\text { Marketing and } \\
\text { relationships }\end{array}$} & $\begin{array}{l}\text { Relationships characterized by individualistic } \\
\text { and opportunistic behavior. }\end{array}$ & $\begin{array}{l}\text { Through SCM approach the relationships could be } \\
\text { improved where all the chain actors focus on satisfying } \\
\text { ultimate customers and improving overall performance } \\
\text { of the whole chain. }\end{array}$ \\
\hline & & $\begin{array}{l}\text { No strong trust based relationships among the } \\
\text { chain actors and no ultimate customer } \\
\text { conceptualization. }\end{array}$ & $\begin{array}{l}\text { SCM creates system thinking where chain actors develop } \\
\text { win-win partnerships and an attitude of winning the } \\
\text { competition all together as a chain, not as individual } \\
\text { business. }\end{array}$ \\
\hline
\end{tabular}

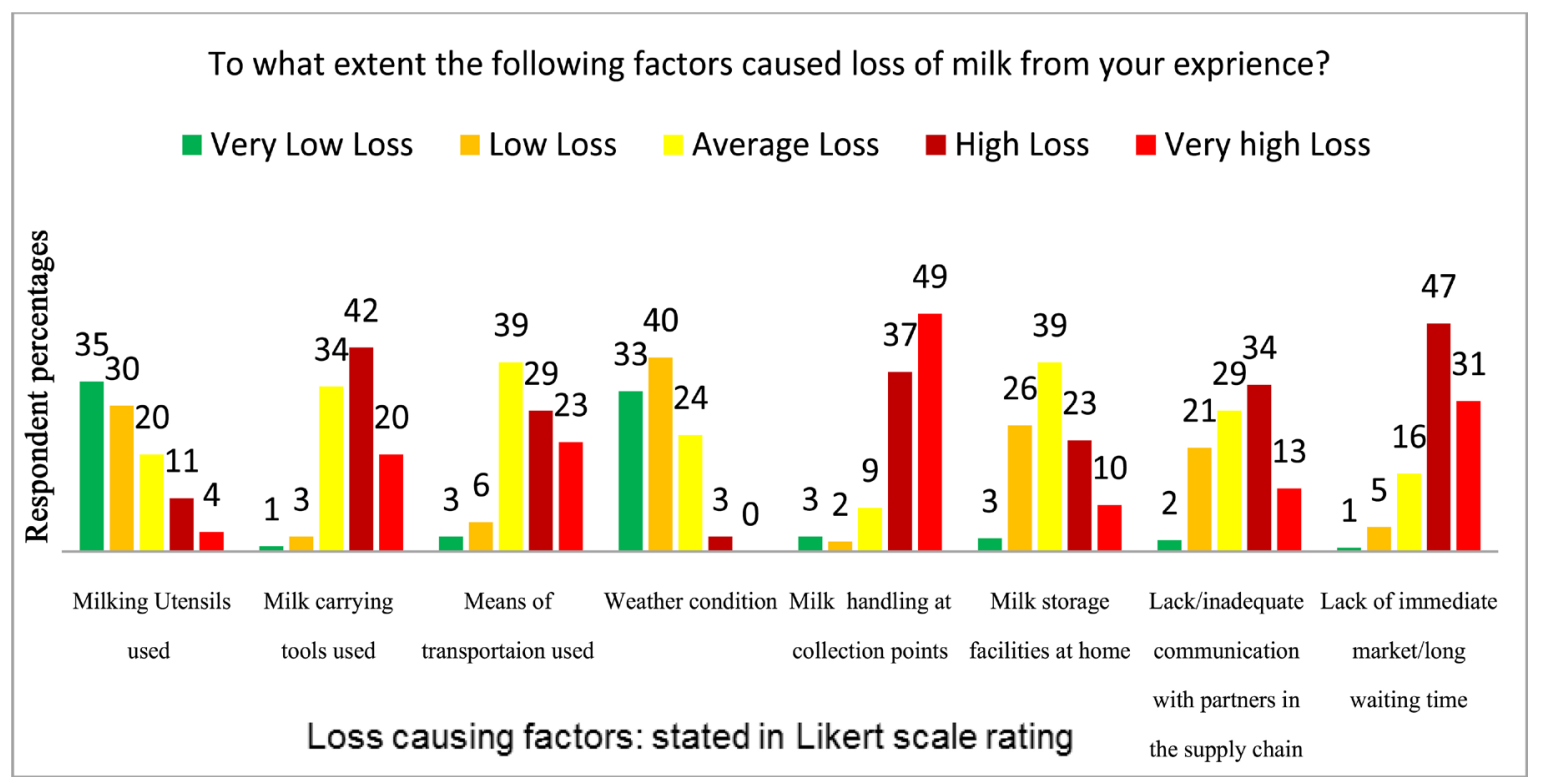

Figure 13. Factors causing milk losses.

impact on their performances. According to the result presented in Figure 14, the support both from governmental and non-governmental organizations was unsatisfactory to the majority of respondents.

The result of political legal environment as presented in Figure 15 was stated to be secure but the physical infrastructure like roads and provisions of utilities like electricity and water were stated as major constraints hindering the daily business of the chain actors in the study area. 


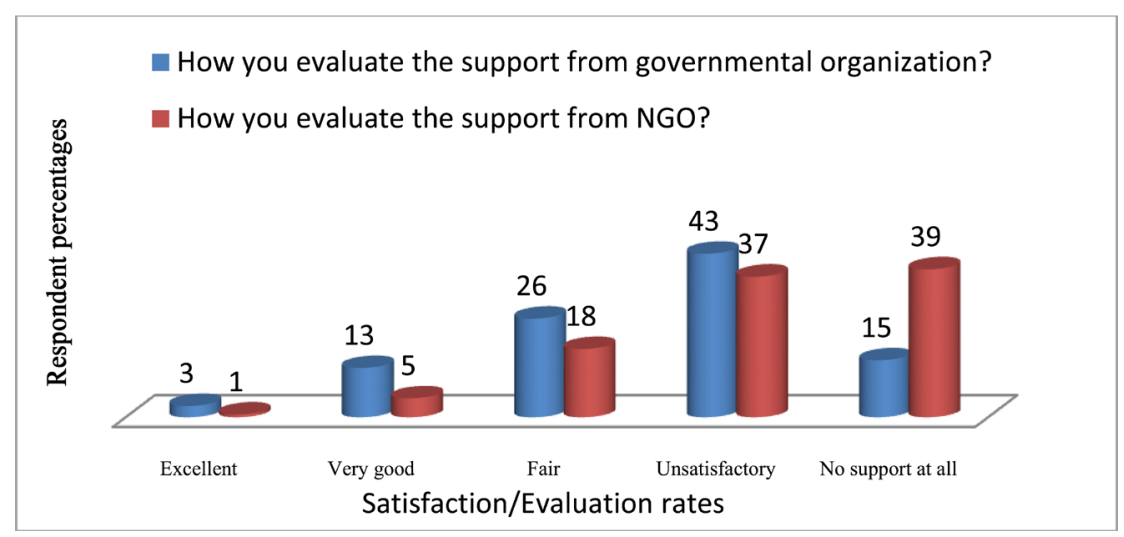

Figure 14. Chain actors' evaluation of support from governmental and non-governmental organizations.

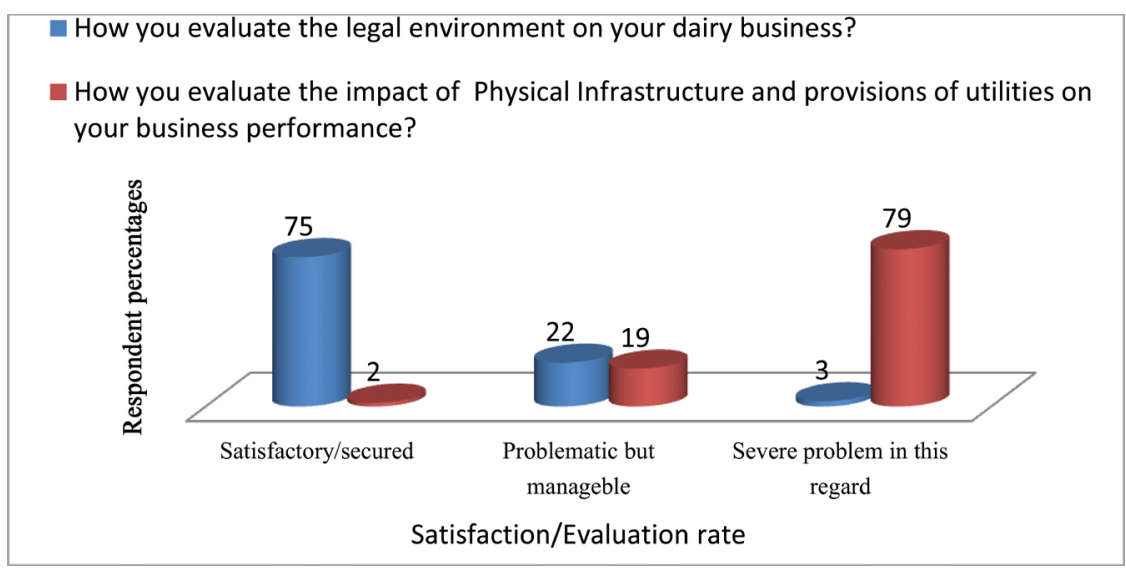

Figure 15. Chain actors' evaluation of legal political environment and physical infrastructure and provisions of utilities impact on their performances.

\section{Discussions}

Marketing relationships and supply chain management: Marketing relationships and supply chain management: The marketing relations among the majority of these chain actors were not going beyond the instant buyingselling relations. It lacks long-term market orientation from value chain perspectives [19], defined long-term market orientation as a situation that goes beyond particular actor and comprising the interaction among the value chain actors in creating value for the end user. It is the concept that profitability for particular chain actor and for the whole chain is possible through focus on customers down the chain or the end users. But in this case study, we found that individualistic market orientation. Farmers' relations with the cooperatives/union has some element of long-standing relationship but does not emphasize the value chain perspective market orientation; farmers' response to the reasons why they were selling to the cooperatives/unions were: the profit they share at the end, the continued access to market (others may stop buying when demand goes down, example is fasting seasons by Orthodox Christians in Ethiopia), and some have no other alternative buyers in the area. Nothing has been mentioned of serving the end customer either by the cooperatives/unions or by the farmers and no conceptualization of the overall profitability to the whole chain, in general. From supply chain management point of view, overall supply chain profitability can be achieved with effective match between demand and supply if strong cooperation is established among the chain members Sirdharan, (2002) cited in [20]. Farmers' relationships with input supplier, which was identified as just only spot market relations, is another indication for further work on relationships management in this milk chain. With the back traceability and trust behaviors in effective supply chain management, an advantage for quality input could be achieved. Contrary to this, farmers in this case study have claims regarding the cow feed quality problems. The framers claimed "we faced situation where our milk was rejected due to milk quality which emanates from feed quality.” However, the information from 
the buyers' side indicated milk was rejected either because of microbial development or because of water adulterations. This is an indication of weak supply chain management across the chain where the chain actors think different causes for the same problem and no common understanding and determination for common solution. The opportunistic behavior, either by input supplier by providing low quality feed or by farmers through water adulteration emanated from lack or inadequate concern for the overall chain profitability, which is central theme of supply chain management.

Dairy product losses and supply chain management: In case studied milk chain, the milk loss was important problem. Though the milk loss quantification was made based on subjective estimates, may be difficult to trust the figures, the existence of significant amount of milk losses in the milk supply and marketing chains was an evident. From the results, the major reason for the losses can be argued as the inefficiencies and ineffectiveness of the supply chain. The problems related to milk handling practice at collection points, lack of immediate acceptors and long waiting time at the collection points, milk carrying tools used, means of transport used, and ineffective communication with the other partner could be addressed through supply chain management. Some of these problems emanated from the relationship management problems. An example was the inadequate communication in the chain, i.e., farmers claimed that sometimes they were waiting at the milk collection points, but the collector/buyer fail to come due to various problems without communicating with the producers. Hence, producers loss both their time, milk or economic values. The other problems were mostly related to logistics functions. The problems of equipment used, transportation mechanism, problems at the collection points, and lack of cooling systems at home, at collection points, and during transportation were few examples of logistics problems observed in the study. These could be addressed through logistics function improvement across the milk supply chain. To this end, the overall chain actors' commitments to make necessary investments at required stages are critical. For instance, most farmers in the sampled study had no cooling machine even though they have access to electricity, at least in peri-urban areas. The reason is that they have no money to buy it. If the chain works with mutual understanding, then there is possibility of acquiring such necessary equipment by the farmer through an arranged finance system from the processors or traders down the chain, agricultural value chain finance commodities could be thought as possibilities [21]. This can only be possible when the chain is recognized as holistic entity by all actors and that is the role of SCM.

Few evidences on importance of SCM in dairy product chains: With the overall value generation to the whole chain as prime motive, SCM has evolved in food sector in general and dairy industry in particular. Under this section, few evidences on SCM in dairy value chains, in developing countries were discussed so as to enable learning lesson for dairy chains in Ethiopia in general and case studied dairy chain in particular.

With regards to dairy/milk, one may remember India for its successful white revolution in 1970 that includes establishing milk marketing facilities in major cities and milk processing and preserving competences in the rural areas; Anand-pattern dairy cooperatives, today known as Amul dairy, was part of the process that benefited more than ten million farmer families [22]. In that successful story, the role played by SCM was evident. The market opportunity established in different areas and preserving competences in the rural areas converted the inefficiencies and milk losses to profit to the whole chain actors. [23], discussed the importance of SCM practices for improving operational performances of Indian dairy cooperatives and reached on recommendatory conclusions as follow:

- the need of SCM department as separate unit in dairy chain actor organizations with responsibility of managing all activities in the dairy supply chains,

- the need to establish reliable supplier relationships in the dairy industry, and

- the need to maintain safe and clean manufacturing practices as a quality parameter.

In sum, [23] indicated the importance of SCM practices and the need of further improvement in the practices for Indian dairy industry to be efficient and globally competitive. [24], tried to develop SCM model for Andrhra Pradesh State of India with the emphasis on the production and distribution activities within supply chain. The author showed 9.8\% cost savings with developed SCM approach from the existing ones without the SCM scenario.

[25], made discussion on importance of SCM and indicated its potential benefit for dairy industry in China. The author listed the following as benefits of implementation of SCM in dairy chains:

- potential for overall improvement in logistics as result of sharing logistics facilities among members' of the supply chain, avoiding overlapping investments on logistics facilities, establishing information interchange platforms through cooperation of enterprises in the supply chain, and overall working efficiency improve- 
ment of logistics in the supply chain,

- potential for reduction of transaction costs, particularly, the information cost aspect,

- potential for improving customer satisfaction.

[26], also made case study of dairy industry in China with aim of identifying managerial issues to consider in quality control of dairy supply chains. The authors use the 2008 milk adulteration incident in China and evaluated two approaches of supply chain quality control: centralized versus decentralized approaches for supply chain quality control using existing dairy chains. As per the authors' discussion, the centralized quality control approach was the situation of vertical integration where the dairy companies own and control the whole functions in the chain while the decentralized version was a dismantled chain where dairy products were supplied by inexperienced and un-trustful suppliers at different stages. After their investigations the authors identified the following points as important issues for consideration in food supply chain quality control:

- food product quality, particularly for emerging global markets, can be ensured by establishing right supply chains,

- the dependence on inexperienced and non-trustful suppliers of the food commodities could end with dangerous result in terms of food quality,

- as a solution to second problem above, the authors favored the centralized food quality control over the decentralized situation for the causes of milk adulterations incidents in 2008 in China. However, the authors also noted the difficulty/impossibility of centralized or vertical integration type food supply chain and recommended establishing strong partnership among legally independent organizations in the food supply chains instead.

[26], also recommended certain functions of food supply chain management, particular to quality issues such as: "establishing supplier code of conducts", "supplier certification programs", "quality standards with monitoring and control", and "managing integration among the food supply chain functions of production, materials management, distributions, transportation, and systems integrations” among these separate organizations in the food supply chains as potential solutions for dairy supply chain quality control in China.

The milk critical loss point assessment in Kenya [27] indicated that milk loss was mainly caused by spillage and spoilage resulting from poor market access, rejections, handling practices, and electric power-offs at dairy plants. This study report noted a declining trend in milk losses in Kenya, which was achieved through collective actions by chain actors. As per the study recommendations made for Kenya dairy sector to further reduce milk losses, which are relevant for Ethiopian dairy industry in the effort to reduce milk losses includes: at farm site milk collection by the next chain actors, capacity building training programs for farmers on various aspects including how to preserve night milk, introducing quality assurance at different stage of the milk chain and assignment of price incentives to quality milk, and standardized milk handling and transportation containers. To achieve these, the role of collective and collaborative actions among the chain actors was emphasized.

Few scientific works we found concerning the dairy chain matters in Ethiopia also indicated the problems that could be alleviated through SCM. [28], showed the existence of poor linkages among the dairy chain actors and recommended the need for establishing effective linkages among the dairy chain actors. [14], indicated the potential emergence of supermarket-led dairy supply chain in Ethiopia which may bring positive impacts to the dairy sector as expansion of dairy trade. However, the authors also noted the possible challenges of emergence of monopoly power by supermarkets and processors exploiting both farmers and customers, which is an indication for the importance of comprehensive dairy SCM that includes and benefits the whole chain including the farmers. [29], showed that through cooperative based networking and collective actions towards accessing market and better negotiation capacity for small-holder farmers, production and productivity has been improved. [15], also noted the poor dairy value chains in Ethiopia with lack of trust among the chain actors and low level of integrated dairy management practice and recommended the strengthening of dairy cooperatives and further relationships establishment with other chain actors as a solution. [30], noted that about $20 \%-35 \%$ of milk losses in Ethiopia occur as result of problems in milk collection, cooling and transports. The authors discussed the success story of one dairy business, Hiruth, and showed that the establishment of long-term win-win relationship between the dairy business and the small-holder farmers as a key success factor. The implementation of SCM to the dairy chains can be thought just as an implementation of such practices in a larger scale with many chain actors establishing win-win relationships.

How to start SCM approach: SCM as discussed above has already evolved to the food sector. However, it can't be implemented without necessary preparations and commitments by concerned stakeholders. Different 
authors [31]-[33] discussed as prerequisite for implementation of SCM was supply chain orientation (SCO) among chain actors. SCO was defined by Hult et al. (2008) cited in [33] as "the extent to which there is predisposition among chain members towards viewing the supply chain as an integrated entity.” [32], tried to establish a general framework for SCO while [31], discussed the role of marketing as supportive functions to the creation of SCO among all supply chain actors. All of them noted the importance of SCO as an internal readiness by firms in the supply chain to pursue a systems approach of observing the supply chain as holistically and end customer-centered unit with integration of intra-firm strategic competences and strategies. Though, the detail conceptual works discussed by these authors on SCO are beyond the scope of this paper, the internal readiness to implement the SCM among the supply chain actors is relevant issue to consider. In this regard, for the case studied dairy chain, the need of promoting SCO by all chain actors is important. Governmental and nongovernmental stakeholders need to work on facilitation of establishment of understanding of each other and having minimum common goals among the chain actors. This may be possible through creations of platforms among chain actors and the stakeholders of the sector.

To sum, SCM could improve the dairy chains of Ethiopia in general and the case studied dairy chain in particular. However, we like to stress that the SCM we are recommending is the one with broader sense, which is not demanding vertical integration type of coordination rather coordination through the formation of partnerships and trust among the legally separate chain actors through collective actions and decisions as noted by Stadtler, (2008) cited in [34]. To this end, we recommend detailed further study of the governance structure and performance measurement and management methods for dairy chains in Ethiopia.

\section{Conclusion and Recommendation}

In this study we have attempted to describe cow milk supply and marketing chain in two districts of central Ethiopia. The result showed that farmers, cooperatives/union, traders, and catering institutions were the major chain actors. Cooperatives/union may be considered as a focal firm in this supply chain because of the marketing potential they have to influence both backward and forward in the chain. At the same time, cooperatives/ unions were identified as a critical milk loss point in the chain. Production was characterized by smallholder farmers with small number of cows and low productivity of milk per cow per day. For farmers, lack of access to finance was identified as the most constraining factor hindering production. Marketing relationships among the chain actors were characterized as lacking long-term market orientation and were specific to transactions. High opportunistic behavior was observed such as farmers claiming the feed quality for the low quality milk and the buyers claiming the farmers for water adulterations. The enabling environment of the dairy chain was identified as an issue that needs improvement. Using the subjective estimate made by the chain actors, losses of milk in the chain were attempted to be quantified; though the quantitative estimates were rough, it was evident for existence of significant milk loss in this milk chain. Milk handling practice at collection points, lack of immediate acceptor, milk carrying tools used, means of transport used, and lack or ineffective communication with other partner in the chain were identified in order of severity as important problems causing milk losses in the study area. We indicated the potential of supply chain management to alleviate the existing problems and for overall improvement of the dairy chain in Ethiopia in general and for the studied dairy chain in particular. To this end, we recommended the promotion of requirements for the implementation of supply chain management approach such as the supply chain orientation (SCO), trust based partnership formation, and value chain perspective market orientations among the chain actors.

\section{Acknowledgements}

We are grateful to RELOAD project for funding the activities of this study. Particularly, we are thankful to Professor Oliver Hensel and Mr Michael Hesse (RELOAD project coordinators), Ambo University, and Swedish University of Agricultural Science, department of Energy and Technology for supporting this study in all dimensions. Our special thanks also go to all chain actors who provided with the data and technical support. Thank you all!

\section{References}

[1] Godfray, H.C.J., Beddington, J.R., Crute, I.R., et al. (2010) Food Security: The Challenge of Feeding 9 Billion People. Science, 327, 812-818. http://dx.doi.org/10.1126/science.1185383 
[2] Parfitt, J., Barthel, M. and Macnaughton, S. (2010) Food Waste within Food Supply Chains: Quantification and Potential for Change to 2050. Philosophical Transactions of the Royal Society B: Biological Sciences, 365, 3065-3081. http://dx.doi.org/10.1098/rstb.2010.0126

[3] Tomlinson, I. (2013) Doubling Food Production to Feed the 9 Billion: A Critical Perspective on a Key Discourse of Food Security in the UK. Journal of Rural Studies, 29, 81-90. http://dx.doi.org/10.1016/j.jrurstud.2011.09.001

[4] WFP, Hunger Map of (2014) World Food Programme. Rome.

[5] Kummu, M., et al. (2012) Lost Food, Wasted Resources: Global Food Supply Chain Losses and Their Impacts on Freshwater, Cropland, and Fertiliser Use. Science of the Total Environment, 438, 477-489. http://dx.doi.org/10.1016/j.scitotenv.2012.08.092

[6] Aulakh, J. and Regmi, A. (2013) Post-Harvest Food Losses Estimation-Development of Consistent Methodology. In: Selected Poster Prepared for Presentation at the Agricultural \& Applied Economics Association's 2013 AAEA \& CAES Joint Annual Meeting, Washington DC.

[7] Lore, T., Omore, A. and Staal, S. (2005) Types, Levels and Causes of Post-Harvest Milk and Dairy Losses in SubSaharan Africa and the Near East. Phase Two Synthesis Report.

[8] Christopher, M. (2011) Logistics and Supply Chain Management. 4th Edition, Prentice Hall, London.

[9] Mena, C. and Stevens, G. (2010) Delivering Performance in Food Supply Chains. Woodhead Publishing Limited, Cambridge. http://dx.doi.org/10.1533/9781845697778

[10] Otte, T.H.J. (2010) Pro-Poor Livestock Policy Initiative-A Living from Livestock: Status and Prospects for Smallholder Milk Production, A Global Perspective. Food and Agriculture Organization of the United Nations, Rome.

[11] Hodges, R.J., Buzby, J.C. and Bennett, B. (2011) Postharvest Losses and Waste in Developed and Less Developed Countries: Opportunities to Improve Resource Use. The Journal of Agricultural Science, 149, 37-45. http://dx.doi.org/10.1017/S0021859610000936

[12] Harris, K.L. and Lindblad, C.J. (1978) Post-Harvest Grain Loss Assessment Methods. America Association of Cereal Chemist, Minneapolis, 193.

[13] CSA (2012) Report on Livestock and Livestock Characteristics. Federal Democratic Republic of Ethiopia Central Statistical Agency, Statistical Bulletin 532.

[14] Francesconi, G.N., Heerink, N. and D’Haese, M. (2010) Evolution and Challenges of Dairy Supply Chains: Evidence from Supermarkets, Industries and Consumers in Ethiopia. Food Policy, 35, 60-68. http://dx.doi.org/10.1016/j.foodpol.2009.06.003

[15] Land O’Lakes, Inc. (2010) The Next Stage in Dairy Development for Ethiopia—Dairy Value Chains, End Markets and Food Security. USAID.

[16] Olsson, U. (2011) Statistics for Life Science I. Studentlitteratur, Lund.

[17] Likert, R. (1974) A Method of Constructing an Attitude Scale. In: Maranell, G.M., Ed., Scaling: A Sourcebook for Behavioral Scientists, Aldine Publishing, Chicago, 233-243.

[18] Tadesse, M. and Dessie, T. (2003) Milk Production Performance of Zebu, Holstein Friesian and Their Crosses in Ethiopia. Livestock Research for Rural Development, 15, 1-9.

[19] Grunert, K.G., Jeppesen, L.F., Jespersen, K.R., et al. (2005) Market Orientation of Value Chains: A Conceptual Framework Based on Four Case Studies from the Food Industry. European Journal of Marketing, 39, 428-455. http://dx.doi.org/10.1108/03090560510590656

[20] Navarro, E.F., Faure, G., Cortijo, E., et al. (2015) The Impacts of Differentiated Markets on the Relationship between Dairy Processors and Smallholder Farmers in the Peruvian Andes. Agricultural Systems, 132, 145-156. http://dx.doi.org/10.1016/j.agsy.2014.10.003

[21] Miller, C. and Jones, L. (2010) Agricultural Value Chain Finance, Tools and Lessons. Food and Agriculture Organization of the United Nations and Practical Action Publishing.

[22] Padmanabhan, B.S. (1978) Towards a White Revolution. Indian Dairyman, 30, 761-763.

[23] Kumar, R. (2014) Dairy Supply Chain Management (DSCM) Practices: An Imperative Solicitation. American Journal of Nutrition and Food Science, 1, 17. http://dx.doi.org/10.12966/ajnfs.04.01.2014

[24] Subbaiah, K.V., Rao, K.N. and Babu, K.N. (2009) Supply Chain Management in a Dairy Industry-A Case Study. In: Proceedings of the World Congress on Engineering, International Association of Engineers, Hong Kong, 595-599.

[25] Lin, B. (2005) SCM in China Dairy Industry. In: Li, Q. and Liang, T.P., Eds., Proceedings of the Seventh International Conference on Electronic Commerce, Volume 1 and 2, Selected Proceedings, Association for Computing Machinery, New York, 821-823. http://dx.doi.org/10.1145/1089551.1089709

[26] Chialin, C., Jun, Z. and Delaurentis, T. (2014) Quality Control in Food Supply Chain Management: An Analytical 
Model and Case Study of the Adulterated Milk Incident in China. International Journal of Production Economics, 152, 188-199. http://dx.doi.org/10.1016/j.ijpe.2013.12.016

[27] FAO (2014) Food Loss Assessments: Causes and Solutions: Case Studies in Small-Scale Agriculture and Fisheries Subsectors in Kenya. Food \& Agriculture Organization of the United Nations, Rome.

[28] Seifu, E. and Doluschitz, R. (2014) Analysis of the Dairy Value Chain: Challenges and Opportunities for Dairy Development in Dire Dawa, Eastern Ethiopia. International Journal of Agricultural Policy and Research, 2, $224-233$.

[29] D’Haese, M., Francesconi, G.-N. and Ruben, R. (2007) Network Management for Dairy Productivity and Quality in Ethiopia. In: Theuvsen, L., Spiller, A. and Peupert, M., Eds., Quality Management in Food Chains, Wageningen Academic Publishers, Wageningen, 185-197.

[30] Juettner, U. and Christopher, M. (2013) The Role of Marketing in Creating a Supply Chain Orientation within the Firm. International Journal of Logistics Research and Applications, 16, 99-113. http://dx.doi.org/10.1080/13675567.2013.799636

[31] Esper, T.L., Defee, C.C. and Mentzer, J.T. (2010) A Framework of Supply Chain Orientation. International Journal of Logistics Management, 21, 161-179. http://dx.doi.org/10.1108/09574091011071906

[32] Schulze-Ehlers, B., et al. (2014) Supply Chain Orientation in SMEs as an Attitudinal Construct Conceptual Considerations and Empirical Application to the Dairy Sector. Supply Chain Management-An International Journal, 19, 395412. http://dx.doi.org/10.1108/SCM-07-2013-0241

[33] Farahani, R.Z. and Hoda Davarzani, N.A. (2009) Supply Chain and Logistics in National. International and Governmental Environment-Concepts and Models, 1-316.

[34] Rao, G.N. (2007) Statistics for Agricultural Sciences. BS Publications, Hyderabad.

[35] Galmessa, U., et al. (2013) Dairy Production Potential and Challenges in Western Oromia Milk Value Chain, Oromia, Ethiopia. Journal of Agriculture and Sustainability, 2. 


\section{Annex 1: Formulas and Estimated Calculations}

\section{a) Average production per cow per day for the whole sampled farmers}

Mean estimation formula for using interval frequency data midpoint approach [35], was used to estimate average milk production per cow per day for both breeds separately.

$$
\begin{aligned}
& \text { Average milk production percow per day }(\text { hybrid cow })=\sum \frac{\left(X_{H L}+X_{H M}\right) \times R_{i}}{2} \\
& \text { Average milk production percow per day (Local cow })=\sum \frac{\left(X_{L L}+X_{L M}\right) \times R_{i}}{2}
\end{aligned}
$$

where; $X_{H L}$-is minimum value production in the range for hybrid cow, $X_{H M}$-is the maximum value production in the range, $X_{L L}$-is the minimum value production in the range for local cow, $X_{L M}$-is the maximum value production in the range for local cow; $R_{l}$-is percentage of respondent in that particular range.

$$
\begin{aligned}
& \text { For hybrid cow }=\left(\frac{16+20}{2}\right) \times 0.08+\left(\frac{11+15}{2}\right) \times 0.34+\left(\frac{8+10}{2}\right) \times 0.40+\left(\frac{5+7}{2}\right) \times 0.18 \\
& =1.44+4.42+3.6+1.08=\underline{\underline{10.54}} \\
& \text { For local cow }=\left(\frac{3+4}{2}\right) \times 0.42+\left(\frac{1+2}{2}\right) \times 0.53+\left(\frac{5+7}{2}\right) \times 0.05 \\
& =1.47+0.795+0.3=\underline{\underline{2.57}}
\end{aligned}
$$

b) Average number of cows per household (without referring to the type of breed)

The mean number of cows per household was estimated by using midpoints of the frequency Table 1 for number of cows and respondent frequency [35].

$$
\text { Estimated mean number of cows per household }=\frac{\sum\left(\frac{X_{i L}+X_{i M}}{2}\right) F_{i}}{\sum F_{i}}
$$

where: $X_{i L}$-is the lower boundary value of the range, $X_{i M}$-is the upper boundary value of the range, and $F_{i}$-is the frequency or number of respondent of the range.

$$
\begin{aligned}
& =\frac{\left(\left(\frac{1+3}{2}\right) \times 18\right)+\left(\left(\frac{4+5}{2}\right) \times 133\right)+\left(\left(\frac{6+8}{2}\right) \times 80\right)+\left(\left(\frac{9+10}{2}\right) \times 19\right)+\left(\left(\frac{11+15}{2}\right) \times 7\right)+\left(\frac{15+25}{2}\right) \times 5}{262} \\
& =(36+598.5+560+180.5+91+100) / 262 \\
& =5.97=6 \text { cows and } 50 \% \text { or } 3 \text { cows assumed as active milking cows per household. }
\end{aligned}
$$

Hybrid to Local Cow proportion: From Table 1, we estimated 2:1 proportion for hybrid:local cows.

\section{c) Estimated losses at each stage}

Losses at farmer level

$=($ Average number of Active milking cow per household

$\times$ production per cow per day) $\times$ estimated percentage of loss

$=((2 \times 10.54) \times 0.0335)+((1 \times 2.57) \times 0.0335)$

$=0.79$ liter per household per day;

Thus, $0.79 \times 262=207$ liters of milk loss per day for the whole sampled farmers

Losses at Cooperatives and Union

$=$ milk production per household per day $\times$ percentage of milk sold by farmers

$\times$ percentage of milk sold to coops and union $\times$ estimated milk loss percentage at this stage 
milk production per household per day $=2 \times 10.54+2.57=23.65$ (2:1 hybrid:local cow proportion, 10.54 and 2.57 average milk production per cow per day, and 3 active milking cows assumption)

percentage of milk sold by farmers

$=100 \%$ - loss percentage - home consumption rate

$=100 \%-3.335 \%-8 \%=88.67$

the $8 \%$ home consumption was taken from study in same area [21].

$23.65 \times 0.8867 \times 0.73 \times 0.0546=0.84$ liters milk losses per household; about 219 liters milk losses for the total sampled farmers per day

Losses at Wholesalers =

Wholesalers buy fresh milk from two sources (Figure 1) i.e., $18 \%$ of what the farmer sale and $48 \%$ of what the coops/unions sale. Therefore, loss at wholesale per household was estimated as

$=0.024(0.18 \times 23.65 \times 0.8867)+(0.48 \times 23.65 \times 0.8867 \times 0.73 \times 0.9454)$

$=0.26$ liters of milk losses per household; amounting to 67 liters of milk losses

for the total sampled farmers per day

Note: wholesalers reported that they didn't encounter losses on processed milk. Also note 0.9454 (94.54\%) of the milk purchased by cooperatives was sold out because there was $5.46 \%$ loss at the stage.

Losses at Processors $=$

Processors buy fresh milk from three sources (Figure 1) i.e., 6\% of what the farmer sale and $17 \%$ of what the coops/unions sale, and 58\% of what the wholesaler sale. Therefore, loss at processor per household was estimated as

$$
\begin{aligned}
& 0.0123(0.06 \times 23.65 \times 0.8867)+(0.17 \times 23.65 \times 0.8867 \times 0.73 \times 0.9454) \\
& +0.58(0.18 \times 23.65 \times 0.8867)+(0.48 \times 23.65 \times 0.8867 \times 0.73 \times 0.9454)
\end{aligned}
$$

$=0.12$ liters of milk losses per household; amounting to 32 liters of milk losses per day for the sampled number of households.

Losses at retailors \& catering institutions =

Retailors \& catering institutions also buy fresh milk from three sources (Figure 1) i.e., 1\% of what the farmer sale and $23 \%$ of what the coops/unions sale, and $42 \%$ of what the wholesaler sale. Therefore, loss at retailor per household was estimated as

$0.0183(0.01 \times 23.65 \times 0.8867)+(0.23 \times 23.65 \times 0.8867 \times 0.73 \times 0.9454)$

$+0.42(0.18 \times 23.65 \times 0.8867)+(0.48 \times 23.65 \times 0.8867 \times 0.73 \times 0.9454)$

$=0.15$ liters of milk losses per household; amounting to 39 liters of milk losses per day for the sampled number of households. Retailors also noted the losses happen only on fresh milk.

Losses in the chain as percentage of total production

$$
=\frac{\text { total estimated losses at all stages of the chain per day }}{\text { total estimated milk production per day }} \times 100 \%
$$

$$
\frac{207+219+67+32+39}{6196} \times 100 \%=\frac{564}{6196} \times 100 \% \approx 9 \%
$$

Total estimated production

$=$ average production per cow per day $\times$ sample size

$$
=23.65 X 262=6196
$$

Note: these quantification attempts were rough and based on the result of the subjective estimates from the respondents with additional assumptions. 
Annex 2: Study Site

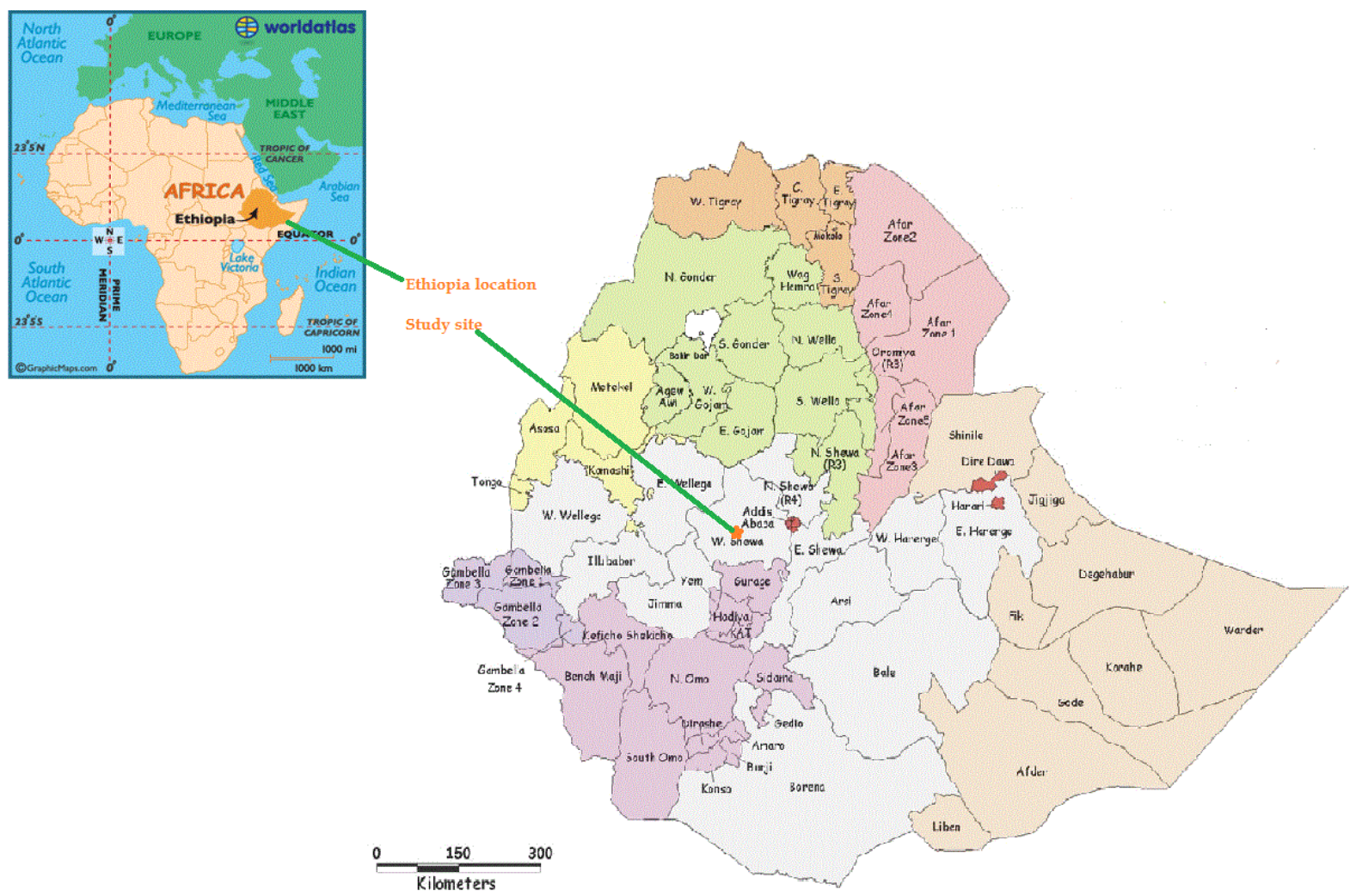

